\title{
Emergence of Collective Action in a Groundwater Commons: Irrigators in the San Luis Valley of Colorado
}

\author{
Kelsey C. Cody ${ }^{1}$, Steven M. Smith ${ }^{2}$, Michael Cox ${ }^{3}$, Krister Andersson ${ }^{4}$ \\ ${ }^{1}$ Corresponding Author: Environmental Studies Program, University of Colorado, Boulder, 397 \\ University of Colorado, Boulder, Colorado, 80309, United States, codykc@ colorado.edu, 1 (707) \\ 333-3776 \\ ${ }^{2}$ Department of Economics and Environmental Studies, Haverford College, 370 Lancaster \\ Avenue, Haverford, Pennsylvania, 19041, United States, ssmith4@ haverford.edu \\ ${ }^{3}$ Environmental Studies Program, Dartmouth College, 6182 Steele Hall, Room 113 \\ Hanover, New Hampshire, 03755, United States, michael.e.cox@ dartmouth.edu \\ ${ }^{4}$ Department of Political Science, University of Colorado, Boulder, 333 University of Colorado, \\ Boulder, Colorado, 80309, United States, anderssk@ colorado.edu
}

\section{Running Head: Collective Action in a Groundwater Commons}

\begin{abstract}
Under what conditions are irrigators able to develop adaptive governance arrangements? This paper addresses this question by developing an empirically-grounded theory of self-governance of a snowmelt commons in Southern Colorado. Drawing on previous work in collective action and institutional theory, we argue that self-regulation of the hydro-commons is driven by changes in shared user perceptions with regards to the salience and scarcity of the resource, as well as the perceived probability of salvaging the resource system. We further posit that several conditioning factors affect the likelihood of effective local responses, including the existing institutional arrangements for self-governance, techno-institutional complementarities, and vested interests. We test and refine our theoretical argument by conducting a historical analysis of regional responses to hydrologic, social, and institutional disturbances in Colorado's San Luis Valley.
\end{abstract}

Key Words: Adaptation, Collective Action, Common Pool Resources, Governance, Groundwater, Institutional Analysis, Irrigation, Path Dependence, Social-Ecological Systems

Acknowledgements: The first two authors shared equal burdens in drafting this document and executing this research. We owe great thanks to the members of the Rio Grande Basin Roundtable for their openness. Steve Vandiver, Heather Dutton, Travis Smith, and Mike Gibson provided particularly valuable input and advice. We thank Lee Alston and Doug Kenney for their early comments and suggestions on developing this project. Brandon Dittman assisted with preliminary legal research. All remaining errors are the authors' own. We also owe thanks to the reviewers, who provided constructive and insightful feedback. Finally, this work would not be possible without the support of National Science Foundation (Grant BCS-0527165). 


\section{Introduction}

Scientists agree that most irrigated agricultural systems face a dire outlook in light of changing climates coupled with population growth (Arnell et al. 2011; Döll 2009). With water supply decreasing and demand increasing it is very likely that snowmelt-driven systems will come under extreme stress in the decades to come (FAO 2012; Gleick 2003).

Meanwhile, human responses to these challenges are not well understood (Raymond and Robinson 2012). We need a better understanding of the conditions under which irrigators are able to develop governance arrangements that can withstand the existing and future water stress. This paper addresses this question in a snowmelt-driven groundwater commons by developing an empirically-grounded theory of self-governance based on a longitudinal analysis of irrigation management in the San Luis Valley (SLV) of Colorado. It builds on similar work on irrigation governance in the Southwest U.S. that has focused on the traditional Acequia systems of New Mexico (Cox 2014; Cox and Ross 2011). The governance challenges associated with people's shared access to groundwater are common throughout the Western United States (USGS 2013) and around the globe (Morris et al. 2003).

Farmers in the SLV depend on irrigation to sustain their agricultural land. The local governance system has been able to stave off claims from outsiders and has recently created its own regulations on groundwater use, preventing top-down interventions by the state government. The outcomes of these self-governance efforts are still in the making. Nevertheless, the documented existence of a variety of exogenous shocks, the evolution of governance arrangements in response to these shocks, as well as mixed levels of success in collective-action 
make the SLV an excellent case for testing and refining a theoretical argument about the emergence of CPR self-governance.

A large literature has addressed CPR governance, positing conditions that facilitate collective action, e.g. small groups, well-defined resource boundaries, homogenous interests, and multiple collective choice venues (Agrawal 2001; Ostrom 2005). Drawing on institutional adaptation literature (Chhetri et al. 2010; Libecap 1989; North 1990), we develop an argument that explicitly incorporates dynamic feedbacks over time, recognizing that past decisions alter the resource, its salience, and shared user perceptions about the probability of being able to salvage it (Gautum and Shivakoti 2005; Oldekop et al. 2012;).

While self-regulation of the groundwater commons is framed by historical adaptations and biophysical constraints, we argue that the likelihood of collective action is further regulated by a set of conditioning factors: broader governance arrangements, vested interests, technoinstitutional complementarities, relative prices, and transaction costs. The contribution of this argument is that it has the potential to explain more completely than existing CPR governance theory why irrigators act collectively in one instance but not in another. Because the more studied demographic and institutional variables (Ostrom 1990) (e.g. population size, economic heterogeneity, property rights, collective choice arrangements, etc.) are relatively constant in our setting, we can test the effects on collective action of our main variables of interest. To demonstrate the theory, we present the institutional evolution of the SLV irrigators from the period of the 1950s to the present day, tracing these conditioning factors and how disturbanceresponse pairs are influenced by past events. Section two discusses the case study site; section three elaborates on the theoretical basis of our analysis; section four describes our data and methods; section five presents and discusses the results; and section six concludes the paper. 


\section{Study Area Description}

The SLV is located in South-Central Colorado, and is delineated by the Sangre de Cristo Mountain range to the east and the San Juan Mountains to the west, each with peaks above 14,000 feet. The valley floor, roughly 3,200 square miles, sits at 7,700 feet above sea level and is roughly 100 miles south-west of Colorado Springs. The SLV receives just 6-9 inches of rain annually. To grow crops, farmers irrigate 95 percent of the cropland. There are complex interactions between ground and surface water and the two layers of the aquifer itself. In general, groundwater extraction, especially to the North of the Rio Grande, affects both the river and the aquifer. Impacts to one well due to pumping at a nearby well have been noted but are hard to disentangle from the overall drop of groundwater levels where wells are dense. The valley's surface water drains primarily into New Mexico through the Rio Grande and Conejos rivers, although a portion drains to a closed basin in the northern end of the SLV where commoditybased agriculture and groundwater wells are most dense. USGS Paper 1379 provides greater detail on the physical complexities (USGS 1958).

Like other arid western states, Colorado adopted the Prior Appropriation Doctrine to allocate water. Under this principle whoever first applies water to a "beneficial use" establishes the right of use in times of shortage. This right is transferable in principle, independent of the appurtenant land. Since 1969 this system is intended to govern water rights for surface and groundwater alike, although groundwater rights remain difficult to monitor and enforce. This has led many irrigators to appropriate groundwater outside of the purview of Prior Appropriation.

Beyond Prior Appropriation, the largest legal constraint to water use in the SLV is the Rio Grande Compact. Finalized in 1938, this legal agreement between Colorado, New Mexico, and 
Texas defines how water from the Rio Grande is to be divided, forcing the SLV to allow a significant amount of water flow to those downstream states.

Recently, alterations in weather patterns have strained the system further. In 2012, the 30-year moving average flow of the Rio Grande was 85 percent of the 1930 measure (USGS 2014). Average temperatures have risen 1.0 degree Celsius since 1993, delaying season ending frost 10 days (Mix et al. 2011) and advancing peak snowmelt runoff 16 days since 1971 (Skiles et al. 2012), increasing the time between peak water supply and demand, independent of overall supply decreases.

Uncoordinated individual pumping after the 2002 drought caused a major decrease in the ground water availability: the five-year running average of aquifer levels fell by approximately $1,000,000$ acre feet (AF) after only falling approximately 200,000 AF over the prior 26 years (RGWCD 2014). Below we address how past disturbances and their responses contributed to this outcome, but also how the irrigators eventually responded by imposing self-regulation.

\section{Theoretical Background}

\section{Institutions and Common Pool Resources}

Building on the literature introduced in Section 1, our analysis is based on the concepts of (1) collective-action problems, (2) common-pool resources (CPRs), (3) institutional path dependence, and (4) disturbances to social-ecological systems (SES). A collective action problem occurs when group members' individual interests get in the way of achieving what is best for the group as a whole. Because CPRs are rival in consumption yet difficult to exclude others from, one primary collective action problem the SLV irrigators face is motivating individuals to constrain their individual consumption of water and exclude new entrance. A 
second collective action problem that local irrigators face is motivating individual group members to contribute to infrastructure that makes effective water appropriation possible - often including infrastructure and institutional arrangements.

The CPR literature has identified several factors that can incentivize collective action, including effective leadership, high social capital, repeated stakeholder interactions and communication, well-defined resource and problem boundaries, and a smaller, roughly homogenous population of users (Agrawal 2001; Ostrom 1990). The importance of all of these variables is in affecting the costs and benefits of cooperation as participants perceive them. Much of the theory of collective action reduces to what counts as costs and benefits and how they are distributed (Axelrod 1984; Boyd and Richerson 1992; Nowak 2006); ecosystem services (e.g. snowpack, groundwater, soils, etc.) are often unaccounted for, and are often CPRs. Collective action, then, is dependent on the model of human behavior that is selected and the costs and benefits of the different outcomes considered by the actor as those costs and benefits relate to their preferences. The model of human behavior we assume here is supported by existing literature (Jones 2001; Ostrom 2005; Poteete et al. 2010), where we regard humans as boundedly rational self-interested actors who largely adhere to group norms (Cox 2014).

Additionally in our exploration of collective-action in the SLV, we consider the path-dependent nature of institutional change and development, whereby current decisions and the development of human capital are influenced by past institutional and technological commitments (Arthur 1989; Heinmiller 2009; Libecap 2011; Marshall 2005; North 1990). We also recognize the growing literature on SES resilience, which emphasizes the need of systems to adapt to a range of alternative disturbances, yet, for the most part, recognizes that the goal of achieving resilience 
is specific to a particular type of disturbance since each demands a unique response (Carpenter et al. 2001).

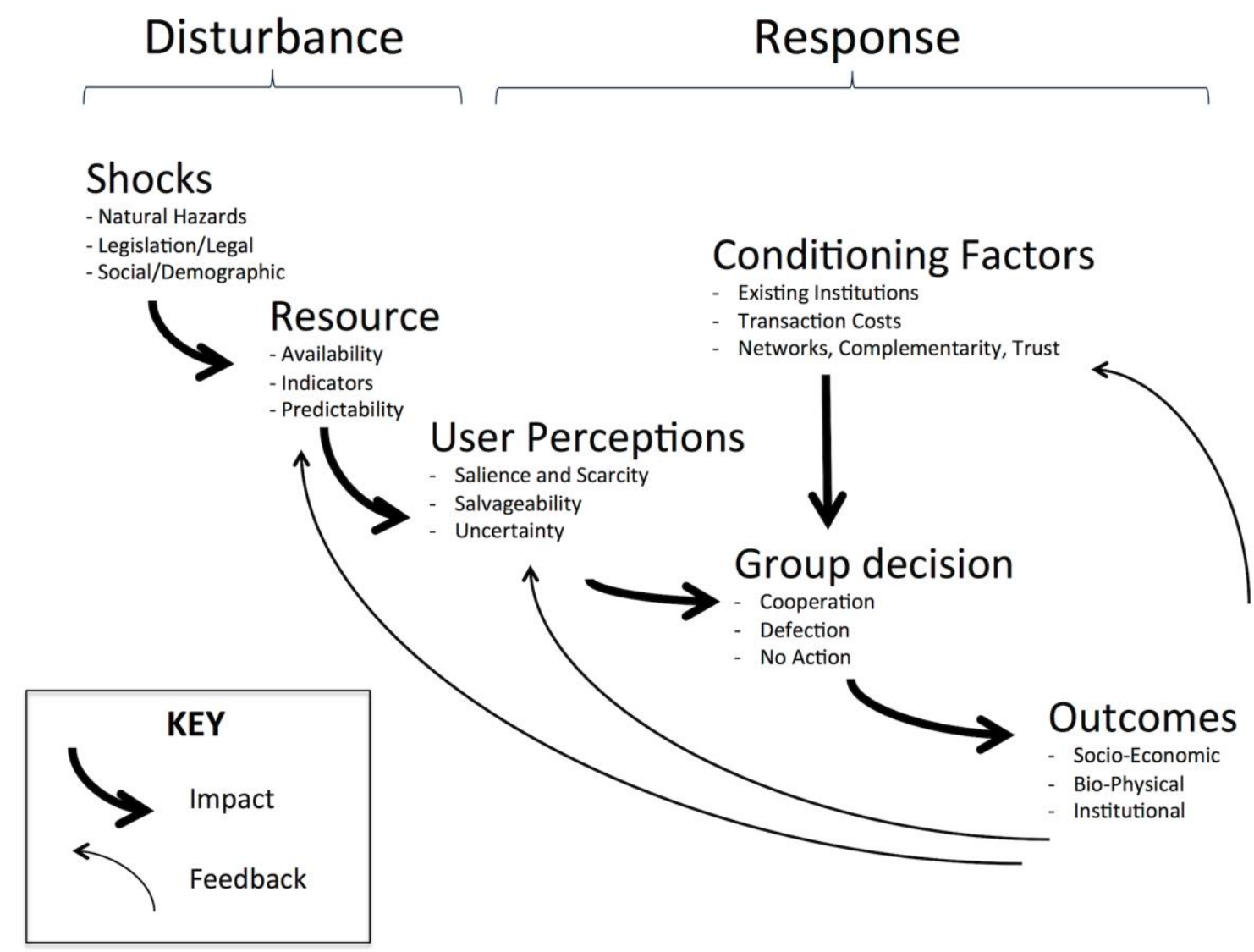

Figure 1 Title: Mechanism for Path Dependence of Collective Action

Figure 1 Caption: Figure 1 depicts our path dependent theory of collective action, showing that the feedbacks created by the outcomes of each response following different kinds of disturbances later influence user perceptions, the resource itself, and other conditioning factors to shape future outcomes and feedbacks. Source: Authors' elaboration based on Ostrom (1990) and Bartley et al. (2008). 
Figure 1 presents a simplified version of the framework we use to combine these perspectives. What we propose here is that collective decisions of resource management are fundamentally driven by the degree to which the resource is perceived by a critical mass of users to be (1) salient; (2) threatened by the status quo, and (3) salvageable (i.e., users believe that the resource is not beyond recovery). These perceptions of how the resource system is changing and its implications for human wellbeing constitute the foundation for local users' motivation to take action. If a critical mass of local users shares these perceptions, it may be that a threshold is reached whereby the status quo is broken and a collective decision is taken to introduce new rules to regulate resource use.

We posit that once a local group is motivated to address their problem, there are several conditioning factors that can affect the likelihood of local users' ability to achieve collective outcomes that are desirable to the group. We argue that these factors affect the users' ability to negotiate any agreement about the users' collective relationship with the resource, including the mechanisms for monitoring and enforcement so that the agreed-upon rules affect individual group members' use of a shared resource. When these conditioning factors are weak or entirely missing, we predict that users will fail to act collectively. Over time, the outcomes of prior disturbances affect the conditioning factors for future disturbances, driving institutional path dependence through feedbacks and processes which alter the characteristics of the actors and their context (Holling 2001; Walker et al. 2004).

\section{Conditioning Factors}

Elaborating on the "conditioning factors" from Figure 1, we hypothesize that there are five drivers related to the path-dependence of institutional change that can affect the causal path 
presented in Figure 1. Synthesized from Heinmiller (2009), Libecap (1989), and North (1990), these factors are:

1. Transaction costs

2. Network effects and techno-institutional complementarities

3. Vested Interests

4. Broader Governance Arrangements

5. Relative prices

By transaction costs we mean the costs of creating, monitoring, and enforcing agreements. In the case of institutional change and adaptation, the term can refer to costs incurred by adopting new institutional arrangements (see Marshall 2005). Many of the more studied variables important for CPR governance are embedded here (e.g. group size, economic heterogeneity, resource boundaries, etc.) (Ostrom 2005).

By network effects we mean the complementarities between interdependent technologies, institutions, and human capital (earlier called "systemic complementarities"). Often, technology, institutions, and human knowledge evolve together, creating effects such that an alteration in the institution would require substantial alteration in complementary technology and techniques as well—the QWERTY keyboard is an often cited example of this process (David 1985). Because of these complementarities, it can be costly to abandon any element in a network when the functionality of other elements depends on it.

By vested interests we mean those actors which prosper disproportionately from a given institutional and technological mix. Given that humans have evolved to be self-interested in important ways, those agents will naturally resist dramatic changes to a status quo and often, due to political power's correlation with economic success, have the ability to do so (Libecap 1994). In the SLV, these vested interests are often the large landholders, senior water rights holders, and 
well users who have resisted paying the costs associated with institutional innovation that may threaten their privileged positions in the group.

Water governance in the SLV is influenced by broader governance arrangements, which sometimes limit, but other times enhance, the flexibility of local decisions (Ostrom 2005). While federal and state environmental laws and policies are growing in complexity, a crucial example in the SLV is prior appropriation: this constitutional level institutional arrangement is unlikely to be modified in the near future.

Finally, relative prices often shift the cost-benefit calculus associated with altering institutions. In contrast to the prior items discussed, these are often a source of change rather than lock-in (North 1990). This means that the likelihood of a new rule being introduced to modify water use is determined in part by how costly it would be not to change existing rules (i.e., the price structure). In the SLV, the crucial factors that drive relative prices are the market value of crops, cost of water, and costs of technology.

In the ensuing historical analysis of institutional change in the governance of water resources in the SLV, we examine the extent to which these factors have shaped governance outcomes.

\section{Methods}

Our analysis is informed by legal briefs and court cases, hydrologic and climatic data, water rights and well administration records, agricultural crop and production data, as well as demographic and census data. These data were validated through ongoing contacts with several key informants from the SLV and by our attendance at public meetings with water officials and users. The repeated visits, which took place from May of 2012 and August of 2013, provided the 
opportunity to observe stakeholders deliberating over water management and policy and investigate details and aspects of the SLV not described in the literature.

The first step in the data analysis involved constructing a basic timeline of events in the SLV. The events selected for analysis as significant shocks were informed by key informants, public meetings, and irrigators. From these events we identify a set of disturbance-response event pairs that were considered to have been important in the institutional evolution of the SLV. Two tasks are conducted with each pair. First, each disturbance is classified by variables identified in Figure 1. Secondly, the response is analyzed with respect to the conditioning factors described above, to examine how (a) the response is constrained by existing conditioning factors, and (b) the outcome constrains future responses. We devote additional attention to one disturbanceresponse pair: the recent implementation of a groundwater subdistrict designed to address the pressing decline in groundwater levels that have been occurring in the SLV.

\section{Results and Discussion}

In this section we describe each disturbance-response dyad in chronological order. Table 1 summarizes these processes for each dyad by listing (1) the precipitating event and disturbance, (2) resource dynamics, (3) users' perceptions, (4) which conditioning factors (e.g. transaction costs) were relevant in the response, (5) what the response was, and (6) what outcomes and feedback resulted. We conclude this section by presenting greater detail concerning the factors which help explain how SLV citizens have successfully overcome the collective action problem to impose costly restraints on personal use of the aquifer water since 2006 (Table 2). 


\begin{tabular}{|c|c|c|c|c|c|c|c|c|}
\hline Time & Event & $\begin{array}{l}\text { Type of } \\
\text { Shock }\end{array}$ & Resource & Perception & $\begin{array}{c}\text { Conditioning } \\
\text { Factors }\end{array}$ & $\begin{array}{c}\text { Collective } \\
\text { Action }\end{array}$ & Outcome & Feedback \\
\hline $\begin{array}{l}1950- \\
1956\end{array}$ & Drought & $\begin{array}{l}\text { Natura } \\
1 \\
\text { Hazard }\end{array}$ & $\begin{array}{c}\text { Rio } \\
\text { Grande } \\
44 \% \\
\text { annual } \\
\text { average } \\
\text { in } 1951\end{array}$ & $\begin{array}{c}\text { Economic } \\
\text { ally salient } \\
\text { scarcity }\end{array}$ & $\begin{array}{c}\text { BGA, NEC, } \\
\text { RP, TC }\end{array}$ & No & $\begin{array}{c}\text { Developed } \\
\text { Ground } \\
\text { Water }\end{array}$ & $\begin{array}{c}\text { Expansion } \\
\text { of aquifer } \\
\text { usage; no } \\
\text { need for } \\
\text { storage } \\
\text { constructio } \\
\text { n }\end{array}$ \\
\hline $\begin{array}{l}1969- \\
1977\end{array}$ & $\begin{array}{c}\text { Compac } \\
\text { t Suit }\end{array}$ & Social & $\begin{array}{c}\text { Perceived } \\
\text { less } \\
\text { future } \\
\text { availabili } \\
\text { ty }\end{array}$ & $\begin{array}{c}\text { Salient, } \\
\text { shared } \\
\text { external } \\
\text { threat }\end{array}$ & NEC, TC, VI & Yes & $\begin{array}{c}\text { Avoided } \\
\text { State } \\
\text { Regulation }\end{array}$ & $\begin{array}{c}\text { Yields } \\
\text { regional } \\
\text { focal } \\
\text { institution; } \\
\text { leaves } \\
\text { aquifer } \\
\text { unregulated }\end{array}$ \\
\hline $\begin{array}{l}1986- \\
2000\end{array}$ & $\begin{array}{c}\text { External } \\
\text { Export }\end{array}$ & Social & $\begin{array}{c}\text { Perceived } \\
\text { less } \\
\text { future } \\
\text { availabili } \\
\text { ty }\end{array}$ & $\begin{array}{c}\text { Salient, } \\
\text { uncertain, } \\
\text { shared } \\
\text { external } \\
\text { threat }\end{array}$ & NEC, RP, VI & Yes & $\begin{array}{c}\text { New } \\
\text { Federal } \\
\text { Law }\end{array}$ & $\begin{array}{c}\text { Social } \\
\text { capital } \\
\text { developmen } \\
\text { t; protects } \\
\text { local } \\
\text { availability }\end{array}$ \\
\hline \multirow[t]{2}{*}{$\begin{array}{l}2002- \\
2004\end{array}$} & \multirow[t]{2}{*}{ Drought } & \multirow[t]{2}{*}{$\begin{array}{c}\text { Natura } \\
1 \\
\text { Hazard }\end{array}$} & \multirow{2}{*}{$\begin{array}{c}24 \% \\
\text { annual } \\
\text { average } \\
\text { in } 2002\end{array}$} & \multirow[t]{2}{*}{$\begin{array}{c}\text { Economic } \\
\text { ally salient } \\
\text { scarcity }\end{array}$} & $\begin{array}{l}\text { NEC, RP, } \\
\text { TC, VI }\end{array}$ & No & $\begin{array}{l}\text { Increased } \\
\text { Pumping }\end{array}$ & $\begin{array}{c}\text { Salient } \\
\text { aquifer } \\
\text { depletion }\end{array}$ \\
\hline & & & & & $\begin{array}{c}\text { BGA, NEC, } \\
\text { TC }\end{array}$ & Yes & $\begin{array}{l}\text { Basin- } \\
\text { wide } \\
\text { planning } \\
\text { group }\end{array}$ & $\begin{array}{c}\text { Social } \\
\text { capital } \\
\text { developmen } \\
\text { t; } \\
\text { unification } \\
\text { of user } \\
\text { perception, } \\
\text { minor } \\
\text { reservoir } \\
\text { projects } \\
\end{array}$ \\
\hline $\begin{array}{c}\text { 2006- } \\
\text { Prese } \\
\text { nt }\end{array}$ & $\begin{array}{l}\text { Ground } \\
\text { water } \\
\text { over- } \\
\text { draft }\end{array}$ & Social & $\begin{array}{c}\text { Large } \\
\text { reduction } \\
\text { in aquifer } \\
\text { level }\end{array}$ & $\begin{array}{c}\text { Monitorin } \\
\text { g clearly } \\
\text { indicates } \\
\text { overdraft, } \\
\text { legal } \\
\text { obligations } \\
\text { to } \\
\text { replenish } \\
\end{array}$ & $\begin{array}{c}\text { BGA, NEC, } \\
\text { TC, VI }\end{array}$ & Yes & $\begin{array}{c}\text { Subdistric } \\
\text { t created }\end{array}$ & $\begin{array}{c}\text { Increase } \\
\text { relative } \\
\text { price of } \\
\text { pumping; } \\
\text { institutional } \\
\text { learning }\end{array}$ \\
\hline
\end{tabular}

LEGEND: Table 1 summarizes the key disturbance-response pairs analyzed, with special attention paid to conditioning factors and user perceptions. KEY: BGA - broader governance arrangements; NEC - network effects/complementarity; RP - relative prices; TC - transaction costs; VI - vested interests

Drought-Expansion of Groundwater Wells in the 1950s

Disturbance From 1950-56, the farmers of the SLV experienced their most severe drought in recorded history up to that time. The shortage of surface water made it clear that 
availability could sharply decrease in any given year. The impact was salient for most farmers, as the drop in productivity impacted their economic wellbeing: 1/3 of the farms were lost from 1950-59 (USDA 2012).

Response Instead of collectively responding to this disturbance, farmers adapted on the individual level by sinking wells into the aquifer. The number of wells increased from 808 to 2,704 during this period. Particularly for junior surface right holders, wells provided a buffer against low flow years in which they may not receive any surface water: during the 1950s, irrigated parcels of junior appropriators, those less resilient to surface droughts, adopted the wells earlier and more densely than senior appropriators did (CDNR 2014). Several factors combined to encourage this response. First, during the 1950s, the price of electricity dropped enough to make the operation of high capacity wells affordable to many SLV farmers. Second, groundwater remained poorly regulated and outside the purview of the surface appropriative system. For the individual farmer in a priority-based system, wells provided a cheap alternative to engaging in collective action to create new institutions for surface-water appropriation (e.g. water markets or reservoirs; Howe et al. 1982).

Feedback With new access to underground aquifers farmers could irrigate further into the growing season. For this reason, along with the efficiency of center-pivot sprinklers drawing on groundwater, senior right holders also adopted new well technology—expanding sprinkler irrigation tenfold between 1950 and 1959. Furthermore, groundwater allowed new entrants, with nearly 600 wells being developed on parcels without surface water rights. Yet, the security provided to each farmer by the wells would lead to new problems of managing the aquifer with thousands of unmonitored points of diversion. In addition, the efficiency of the sprinklers increased consumptive use while decreasing aquifer recharge per unit of water withdrawn 
(Pfeiffer and Lin 2010; Ward and Pulido-Velazquez 2008). This set the stage for later

developments by locking the system into a path of tighter hydrologic interdependence and vested interests. Consolidation led to fewer farmers in the SLV, varying between 1500 and 1700 farms through the present.

\section{Compact Violation-Defeat of State Regulations in 1980s}

Disturbance Groundwater overuse began to harm senior water users in the SLV, as well as New Mexico and Texas, which filed a lawsuit against Colorado for a Rio Grande Compact violation in 1966. The state legislature responded by organizing the SLV into a self-directed administrative unit, the Rio Grande Water Conservation District (RGWCD) in order to better defend itself. Colorado settled the interstate dispute by promising to bring groundwater wells into the prior appropriation system, subsequently passing the Water Rights Administration and Determination Act of 1969. Since many farmers had become reliant on unregulated groundwater wells, irrigators perceived this law as a significant threat to their shared interests.

Response Irrigators responded by cooperating to sue the state after it proposed rules for well regulation in 1975 . The 1984 verdict barred additional wells but protected existing well users from regulation. Groundwater users in other areas of Colorado failed to organize, and the State regulated well use there. Efforts to defeat the State stemmed from strong complementarities in the SLV's irrigation practices and economy; irrigators using center-pivot sprinklers relied on pumps on wells to generate sufficient pressure for the sprinklers. Sprinklers using groundwater were a successful irrigation practice, and significant vested interests had developed that became motivated to prevent well regulation; 33 percent of decreed rights in the valley are for groundwater-twice the ratio of neighboring basins. However, valley-wide collective action 
would have been costly to organize, perhaps prohibitively so, had the state not created the RGWCD and enabled it to legally represent the SLV and collect taxes. The RGWCD organized information, people, and finances around the lawsuit, and thereby substantially reducing transaction costs.

Feedback The social and human capital built through this case created the precedent and tools necessary for more collective action in the SLV. On the one hand, the result closed the commons from additional entrants, forcing new users to obtain rights from the existing pool (and thus raising the price of water). On the other hand, this action effectively prevented the regulation of wells in the SLV for over 40 years (though they did begin to monitor the aquifer). Thus, this collective action maintained a problematic status quo supported by dominant vested interests. With commodity prices remaining high and water prices low, irrigators would continue to over-exploit the aquifer, though abundant precipitation through the 80 s and 90 s minimized the issue and kept the aquifer relatively stable.

\section{Export Threat-Preventative Federal Legislation in the 1990s}

Disturbance Growing demand for water was not limited to the SLV. Social shocks occurred at the state level as the cities of the nearby Front Range (e.g. Denver, Colorado Springs, Pueblo) demanded additional supplies. Often, this water came from agricultural regions within the state. Export threats surfaced in the SLV, with two for-profit companies attempting to establish rights to allegedly unappropriated groundwater near the National Sand Dunes Monument. The export of 200,000 AFY (23 percent of SLV consumption [CDNR 2011]) was perceived by nearly all irrigators and valley residents as a clear external threat to the local availability of water, and thus the viability of the economy. In addition, due to the isolation and 
lack of existing physical infrastructure, SLV residents perceived defeat of external municipal transfers to be possible - without the large transfer to justify the costly infrastructure, smaller transfers would not be possible either.

Response Both export attempts were defeated. The first attempt in 1986 by American Water Development, Inc. (AWDI) was defeated in Water Court in 1991, notably with the largely politically conservative population funding the legal fight by voting to increase taxes on themselves through the RGWCD. Stockman's Water Company later made similar designs to export. The SLV thwarted this attempt through federal legislation, expanding the Sand Dunes into a National Park in 2000, which protects underlying water from any future export attempts.

In this instance, the relative price of water between the basins produced the perceived external threat, while network effects and vested interests along with the existence of the RGWCD permitted the SLV to defeat the external interests. While marginal costs for pumping water faced by irrigators included merely energy costs, urban water could fetch upward of \$5,000/AF. Despite this large gap, the SLV irrigators benefited from community-wide opposition, not just irrigators, due to the centrality of agriculture to the entire region's economy - with farm production directly accounting for 33 percent of the valley's GDP in 2000 (the figure is 12 percent in the Arkansas Basin, home to Colorado Springs, and 4 percent in the South Platte, home to Denver) - making the residents quite homogenous in their general dependence on agriculture. The united position was evidenced by the 77 official objecting parties in the AWDI case. Stockman attempted to erode some of the vested irrigators' political power by imposing \$40/AF pumping fees through a statewide ballot, but this was defeated 3:1 (Quillen 2000). Efforts on all fronts were led by the RGWCD, which by now had become a conduit for local water interests. 
Feedback These processes and outcomes produced a number of feedbacks. Facing a common external threat built social capital among otherwise disparate interests in the SLV. In addition, the formation of the National Park bolstered the tourist sector, relieving some of the economy's reliance on agriculture. Concerning the water resource, the defeat of exportations minimized future outside demand on the resource due to the looming expenses of physically moving it. As with past disturbances, however, their collective action left wells unregulated.

\section{Drought-Groundwater Overdraft and Basin-Wide Planning in the 2000s}

Disturbance 2002 was a record low year in terms of water flows and snowpack (24 percent and 6 percent of respective average levels). The drought meant that the SLV simply could not maintain its historical agricultural production—reducing irrigated acreage by 41 percent from 1997. And the drought lasted: total flow from 2001-2011 was the 7th lowest 10year rolling average in over 100 years, surpassed only by the 1959-1964 averages. Irrigators felt the shortage acutely when no snowmelt came after May in 2002.

Response Like the 1950s drought, irrigators found it easiest to adapt by increasing groundwater pumping, a decision made at the individual level and at the expense of collective interests. Due to the previous success in fending off well regulation, the relative price of pumping more groundwater remained low, and individual irrigators exploited the groundwater rather than paying the high transaction costs necessary to act collectively. Further driving water use, commodity prices of the three major crops grown in the area - alfalfa, barley/small grains, and potatoes - continued to increase. Another impediment to collective action was the heterogeneous interests in the SLV with respect to this particular threat (large, upstream 
groundwater users versus smaller, downstream surface-only users), leading to a spike in water court cases.

The second major outcome of the drought was the formation of a basin-wide planning group. This endeavor was made possible by broader governance arrangements imposed by the state in response to the 2002 drought. The state government responded with the passage of the Colorado Water for the 21st Century Act, which established processes called Basin Roundtables. Held monthly since 2006 in each river basin in Colorado, these meetings have manifested within the SLV as formal gatherings where conversations take place among farmers and ranchers, experts in law, agriculture, and hydrology, and public officials. Many constituents in the SLV have thrived in the Roundtable setting; indeed, they have secured in excess of $\$ 9.0$ million in state funds from 2006-2013, or 26 percent of the total distributed, the most of the state's nine Roundtables (CDNR 2013).

Feedback The Basin Roundtable had the effect of unifying water users in the perception that their supplies were limited and that their ability to continue to irrigate was tied to each other's actions. Combined with the initial uncoordinated response, the duration of the drought caused a decrease in the aquifer level of approximately 1,000,000 AF over the decade. In that vein, the increased instances of communication and ongoing interactions through the Roundtables have increased social capital among irrigators and reduced information costs. Crucially, in its early planning stages, the Roundtable participants agreed that the Rio Grande Basin's primary need was to stabilize the aquifer, even if it would necessitate the imposition of well regulation, something the SLV water users had fought for decades.

\section{Groundwater Depletion-Subdistrict Formation}


Central to our argument about the conditions under which successful local governance of the commons will emerge is the confluence of several factors affecting the likelihood of effective collective action. Table 2 summarizes these factors in the specific context of the SLV. We leverage this final response (unique in the SLV in that they respond to an internal threat with cooperative behavior) to explore more fully the confluence of factors that yield successful local governance of the commons.

TABLE 2. Factors incentivizing the formation of the groundwater subdistrict

\begin{tabular}{|c|c|c|c|}
\hline Category & Incentive & Description & Impact \\
\hline Resource Shock & $\begin{array}{l}\text { Record low } \\
\text { surface flows }\end{array}$ & $\begin{array}{l}\text { Reductions in irrigated } \\
\text { crop land since } 2002 \\
\text { drought and recent aridity }\end{array}$ & $\begin{array}{l}\text { Economic, social, and } \\
\text { psychological stress } \\
\text { induced by status quo }\end{array}$ \\
\hline User Perception & $\begin{array}{l}\text { Groundwater } \\
\text { level data }\end{array}$ & $\begin{array}{l}\text { Wells measuring the } \\
\text { closed basin indicate } \\
\text { storage is } 1,000,000 \mathrm{AF} \\
\text { below } 1976 \text { amount }\end{array}$ & $\begin{array}{l}\text { Visible impact of } \\
\text { unrestrained pumping of } \\
\text { the aquifer }\end{array}$ \\
\hline User Perception & $\begin{array}{l}\text { State } \\
\text { regulatory } \\
\text { threats }\end{array}$ & $\begin{array}{l}\text { State threatens to meter, } \\
\text { curtail, shut down wells }\end{array}$ & $\begin{array}{l}\text { Clear negative } \\
\text { consequence of failed } \\
\text { collective action }\end{array}$ \\
\hline $\begin{array}{l}\text { Conditioning Factors: } \\
\text { Broader Governance } \\
\text { Arrangements, Relative } \\
\text { Prices }\end{array}$ & $\begin{array}{l}\text { External } \\
\text { financial } \\
\text { support }\end{array}$ & $\begin{array}{l}\text { The federal government } \\
\text { has supported the } \\
\text { subdistrict process } \\
\text { through the CREP }\end{array}$ & $\begin{array}{l}\text { Allows the participant to } \\
\text { leverage their investment }\end{array}$ \\
\hline $\begin{array}{l}\text { Conditioning Factors: } \\
\text { Transaction Costs, } \\
\text { Vested Interests }\end{array}$ & $\begin{array}{l}\text { Increased } \\
\text { social capital }\end{array}$ & $\begin{array}{l}\text { Increased communication, } \\
\text { strong regional identity, } \\
\text { and past success in } \\
\text { collective-action }\end{array}$ & $\begin{array}{l}\text { Increases levels of trust } \\
\text { and reputation-building } \\
\text { among the members of the } \\
\text { Subdistrict }\end{array}$ \\
\hline $\begin{array}{l}\text { Conditioning Factors: } \\
\text { Transaction Costs, } \\
\text { Broader Governance } \\
\text { Arrangements }\end{array}$ & $\begin{array}{l}\text { Strong } \\
\text { leadership }\end{array}$ & $\begin{array}{l}\text { RGWCD, local experts, } \\
\text { valley representatives in } \\
\text { state boards, and state } \\
\text { legislators provide much } \\
\text { support }\end{array}$ & $\begin{array}{l}\text { Mediate and provide legal } \\
\text { and technical expertise to } \\
\text { enact the community's } \\
\text { solutions }\end{array}$ \\
\hline $\begin{array}{l}\text { Conditioning Factors: } \\
\text { Network } \\
\text { Effects/Complementarity, } \\
\text { Transaction Costs }\end{array}$ & $\begin{array}{l}\text { Well defined } \\
\text { social and } \\
\text { biophysical } \\
\text { boundaries }\end{array}$ & $\begin{array}{l}\text { The aquifer underlying } \\
\text { the subdistrict is relatively } \\
\text { self-contained, enabling } \\
\text { strong user boundaries } \\
\text { and meaningful feedback }\end{array}$ & $\begin{array}{l}\text { Enables the identification } \\
\text { of a well-defined subset of } \\
\text { SLV users who more } \\
\text { easily establish social } \\
\text { capital and trust }\end{array}$ \\
\hline $\begin{array}{l}\text { Conditioning Factors: } \\
\text { Transaction Costs }\end{array}$ & $\begin{array}{l}\text { Decreased } \\
\text { participant } \\
\text { size }\end{array}$ & $\begin{array}{l}\text { With well-defined } \\
\text { resource and user } \\
\text { boundaries, effective } \\
\text { participant size decreases }\end{array}$ & $\begin{array}{l}\text { Smaller numbers } \\
\text { decreases transaction costs } \\
\text { of collective action }\end{array}$ \\
\hline $\begin{array}{l}\text { Conditioning Factors: } \\
\text { Vested Interests }\end{array}$ & $\begin{array}{l}\text { Homogenous } \\
\text { interests }\end{array}$ & $\begin{array}{l}\text { No asymmetry or strong } \\
\text { divergence of interests } \\
\text { among groundwater users }\end{array}$ & $\begin{array}{l}\text { Increases participant buy- } \\
\text { in }\end{array}$ \\
\hline
\end{tabular}

Table 2 summarizes the key factors which incentivized the formation of the groundwater subdistrict in 2006, illustrating the importance of user perceptions and the influence of past events in shaping incentives. 
Disturbance The 2002 drought became a decade's long slog. The declining aquifer was highly salient to irrigators; not only did individuals encounter increased pumping costs due to lower aquifer levels, but the data gathered by the RGWCD and communicated in the Roundtable and by local media provided a clear, common indicator of the impact of the pumping and of the aquifer's salvageability. Beyond the salience of the CPR's decline, the State began a process of groundwater well regulation through legislation; irrigator inaction would result in clear legal ramifications and substantial pumping limitations.

Response From 2002-2005, managers and leaders in the SLV began work on the organization of Special Groundwater Subdistrict 1 of the RGWCD. With other groundwater districts throughout the Western United States and Colorado itself as examples, irrigators in the SLV acted collectively to form one, agreeing upon market-based incentives to reduce their use of the resource rather than command-and-control tools. To enable this, state Senator and farmer Lewis Entz formulated Senate Bill 04-222. This broader governance arrangement protected well users from being shut down by the state if their well operated within a plan adopted by a subdistrict, allowing the RGWCD to meter wells for the first time. The subdistrict became operational in 2009, officially labeled Subdistrict 1.

Subdistrict 1 includes roughly 160,000 acres of irrigated land in the closed basin with 671 irrigators. The subdistrict has several purposes: to augment surface flows for downstream senior surface right holders while also bringing the aquifer to a sustainable level within the Rio Grande Compact. To accomplish these, users developed two tools: (1) compensating farmers to fallow land, taking it out of production; and (2) charging those farmers that continue to pump a fee of $\$ 0-\$ 75 / A F$. Despite earlier opposition to similar fees, 60 percent of the stakeholders approved the formation of the subdistrict and the costs that came with it. 
Cooperation to address the CPR problem through the subdistrict is due to a number of factors, some of which are highlighted in Table 2. First, strong vested interests remained, as farming and ranching continued to be the dominant economic activity. With strict external regulation looming, internal compromise was incentivized. Second, broader governance arrangements with the federal-level Conservation Reserve Enhancement Program (CREP) enhanced the perception of salvageability. The subdistrict could not by itself afford to fund the extent of fallowed land. While 20 percent of the funds would come from the subdistrict, the external subsidy made the program economical for irrigators.

Several other factors have reduced transaction costs to enable this collective action, some conform directly with main features identified in CPR theory, including high levels of communication and increased social capital, past successful experiences with collective action, strong leadership, well-defined resource and user boundaries, decreased group size, and homogeneity of interests.

To begin, members of the subdistrict share a strong regional identity that was enhanced by their past successful efforts at defeating external threats to their water. The social capital created by these successes has been bolstered by: (1) the efforts by the RGWCD to deliberate and discuss with members about the formation of the district before a decision had been made; (2) TV, radio, newspaper, poster, and other outreach and education efforts and public and stakeholder presentations at Roundtable meetings; and (3) an increasingly active local press and public awareness surrounding water, with murals, dedications, and even houses of worship making references to water throughout the SLV. 
Additionally, strong leaders have been shown in many cases to facilitate the provision of important public goods by assuming some of the start-up costs associated with collective action. This is also the case in the formation of Subdistrict 1, as a small group of key individuals did the vast majority of the initial planning. Many leaders serve on multiple organizations while the broader governance arrangement of the RGWCD provides remarkable stability of leadership.

Furthermore, the Subdistrict 1 is located over a well-defined, hydrologically contained portion of the SLV. This feature facilitates cooperation because by focusing on this smaller, relatively homogenous hydrological region it is easier to model and understand the intricacies of the ground-to-surface water connection. On the same token, grouping users together which share the same resource (and not including users of other systems) allows them to grasp their connection to one another hydrologically, producing more homogenous interests. The geographic grouping also provides social mechanisms and norms which lower transaction costs. By reducing the number of relevant stakeholders, costs of bargaining and free-rider opportunities are reduced. Finally, because groundwater lacks a seniority system, the heterogeneity of vested interests is greatly reduced relative to the priority system of surface water. The groundwater regime is also spared the upstream and downstream heterogeneities of the surface regime.

Feedback While an unambiguous example of overcoming collective action problems, it remains unclear if the subdistrict scheme is sufficient to avoid the tragedy of the commons, especially in light of repeated sub-average snowpack years. Even a 30-percent reduction in pumping overall from 2011 to 2012 did not prevent the aquifer level from dropping even further. After low enrollment in the 2013 irrigation season and rising commodity prices, without more participation in the CREP program or several abundant snow years, SLV citizens will once again be forced to adapt its irrigation institutions if it is to manage their shared water resources 
sustainably. Indeed six more subdistricts remain to be developed, having learned from the first; to account for heterogeneities, most intend to allow irrigators to opt in and out of the subdistrict.

\section{Conclusion}

The SLV case study indicates that irrigators are most capable of collective action when a disturbance is external and of a social nature, contrasting with the nearby Taos Acequias studied by Cox (2014) which were poorly able to respond to social stresses. That said, similar to the findings of Cox and Ross (2011), the strongest influence on how this SES has evolved during the past 60 years is drought. Drought in the SLV has driven the most fundamental changes in relation to the resource, from the non-cooperative introduction of high capacity wells to improve reliability of the water supply to the cooperative formation of groundwater subdistricts. Despite a strong set of condition factors conducive to collective action, the recent drought has proven difficult to adapt to for many irrigators, owing largely to its duration and the institutional and technological complementarities which limit irrigators' alternatives in times of shortage. The formation of Subdistrict 1 has been costly due to the institutional and technological complementarities irrigators have, yet other conditioning factors rewarded cooperative strategies.

The formation of the first subdistrict in the SLV stands out for two reasons. First, it is an example of irrigators engaging in collective action, despite the costs, to maintain self-governance of a CPR. Second, the subdistrict is creative in its design and structure; it actively seeks to incorporate many of the features that have been shown to be associated with successful CPR governance, rather than passively through an ongoing process of institutional evolution. It also mimics the structure of other groundwater districts in Colorado, but is unique in its aquifer sustainability mandate, its backing of a basin-wide taxing authority, and the USDA CREP 
program. Successful collective action to form the subdistrict was enabled largely by networks and techno-institutional path dependence (e.g. groundwater dependence) and broader governmental arrangements (e.g. the RGWCD), but ultimately the exogenous shock of the 2002 drought precipitated the subdistrict formation; in the 1950s, groundwater was plentiful. In contrast to drought in 1950s, conditioning factors that developed in the interim made it both beneficial and possible for the irrigators to cooperate and impose costly restraints on themselves. Institutional developments resulting from external social disturbances, disturbances we posit were easier to respond to due to the more uniform user perception of salience and salvageability, provided a context for cooperation, while ground water overdraft created the impetus.

Throughout the world groups of resource users face similar challenges of collective action that are often exacerbated by novel extractive technologies, similar path-dependent constraints from previous adaptations, and bio-physical pressures from their external environments (Berman et al. 2012; Reidsma et al. 2010; Rosenzweig et al. 2004; Varela-Ortega et al. 2011; Waha et al. 2012; Wheeler et al. 2013). While the story is common, the method applied here, combining work on collective action in CPR settings and literature on path dependence, is not. Although much of the work on CPR governance has emphasized the importance of historical context, it has done so mostly in a purely descriptive fashion, without identifying particular elements that drive such historical contingencies and relating them to theoretical predictions. By identifying such elements, given here as conditioning factors, and exploring their associated mechanisms, we can better accumulate knowledge regarding the development of adaptive resource governance within SESs. Thus, in future work we advocate for the continued combination of institutional path dependence and CPR governance theories and to test more arguments about the conditions under which sustainable outcomes are more likely to emerge. 


\section{References}

Agrawal, A. 2001. "Common property institutions and sustainable governance of resources." World Development, vol. 29, no. 10, pp. 1649-1672.

Arnell, N.W., van Vuuren, D.P. \& Isaac, M. 2011. "The implications of climate policy for the impacts of climate change on global water resources." Global Environmental Change, vol. 21, no. 2, pp. 592-603.

Arthur, B.W. 1989. “Competing Technologies, Increasing Returns, and Lock-In by Historical Events." The Economic Journal, vol. 99, no. 394, pp. 116-131.

Axelrod, R. 1984. The Evolution of Cooperation. Basic Books, Cambridge, MA.

Bartley, T., Andersson, K., Jagger, P. \& van Laerhoven, F. 2008. “The Contribution of Institutional Theories to Explaining Decentralization of Natural Resource Governance.” Society and Natural Resources, vol. 21, no.2, pp. 160-174.

Berman, R., Quinn, C. \& Paavola, J. 2012. "The role of institutions in the transformation of coping capacity to sustainable adaptive capacity." Environmental Development, vol. 2, no. 1, pp. 86-100.

Boyd, R. \& Richerson, P.J., 1992. "Punishment Allows the Evolution of Cooperation (or Anything Else) in Sizable Groups.” Ethology and Sociobiology, vol. 13, pp 171- 195.

Carpenter, S., Walker, B., Anderies, J. \& Abel, N. 2001. "From Metaphor to Measurement: Resilience of What to What?” Ecosystems, vol. 4, no. 1, pp. 765-781.

Chhetri, N., Easterling, W., Terando, A. \& Mearns, L. 2010. "Modeling Path Dependence in 
Agricultural Adaptation to Climate Variability and Change." Annals of the Association of American Geographers, vol. 100, no. 4, pp. 894-907.

Colorado Department of Natural Resources (CDNR). 2014. "Well Permit Search.” Accessed Aug. 11, 2014. http://cdss.state.co.us/onlineTools/Pages/WellPermitSearch.aspx

Colorado Department of Natural Resources (CDNR). 2013. Water Supply Reserve Account Annual Report. Denver: Colorado Department of Natural Resources. Accessed Aug. 11, 2014. http://cwcb.state.co.us/public-information/publications/Pages/AgencyReports.aspx

Colorado Department of Natural Resources (CDNR). 2011. Statewide Water Supply Initiative 2010. Denver: Colorado Department of Natural Resources. Accessed Aug. 11, 2014. http://cwcb.state.co.us/water-management/water-supply-planning/pages/swsi2010.aspx

Cox, M. 2014. "Modern disturbances to a long-lasting community-based resource management system: the Taos Valley acequias." Global Environmental Change, vol. 24, pp 213-222.

Cox, M., and Ross, J. 2011. "Robustness and vulnerability of community irrigation systems: the case of the Taos valley acequias." Journal of Environmental Economics and Management, vol. 61 n. 3, pp. 254-266.

David, P.A. 1985. "Clio and the Economics of QWERTY." The American Economic Review, vol. 75 , no. 2 , pp. 332-337.

Döll, P. 2009. "Vulnerability to the impact of climate change on renewable groundwater resources: a global-scale assessment.” Environmental Research Letters, vol. 4, no. 3, pp. 1-12. Food and Agriculture Organization of the United Nations (FAO). 2012. Food Insecurity In the World. Accessed Aug. 11, 2014. http://www.fao.org/docrep/016/i3027e/i3027e.pdf 
Gautum, A. \& Shivakoti, G. 2005. "Conditions for Successful Local Collective Action in Forestry: Some Evidence From the Hills of Nepal." Society \& Natural Resources, vol. 18, no. 2, pp. 153-171.

Gleick, P. 2003. "Global Freshwater Resources: Soft-Path Solutions for the 21st Century." Science, vol. 302, no. 5650, pp. 1524-1528.

Heinmiller, T. 2009. "Path dependency and collective action in common pool governance." International Journal of the Commons, vol. 3, no. 1, pp. 131-147.

Holling, C. 2001. "Understanding the Complexity of Economic, Ecological, and Social Systems.” Ecosystems, vol. 4 no. 5, pp 390-405.

Howe, C.W., Alexander, P.K. \& Moses, R.J. 1982. "The Performance of Appropriative Water Rights Systems in the Western United States During Drought.” Natural Resources Journal, vol. 22, pp. 379-389.

Jones, B.D. 2001. Politics and the Architecture of Choice: Bounded Rationality and Governance. University of Chicago Press, Chicago, IL.

Libecap, G.D. 2011. "Institutional Path Dependence in Climate Adaptation: Coman's “Some Unsettled Problems of Irrigation.” The American Economic Review, vol. 101, pp. 1-19.

Libecap, G.D. 1994. “The Conditions for Successful Collective Action.” Journal of Theoretical Politics, vol. 6, no. 4, pp. 563-592.

Libecap, G.D. 1989. Contracting for Property Rights. Cambridge University Press, Cambridge, UK. 
Marshall, G. 2005. Economics for Collaborative Environmental Management. Earthscan. London, UK.

Mix, K., Lopes, V. \& Rast, W. 2011. “Annual and Growing Season Temperature Changes in the San Luis Valley, Colorado.” Water Air and Soil Pollution, vol. 220, no. 1, pp. 189-203.

Morris, B.L., Lawrence, A.R.L., Chilton, P.J.C., Adams, B., Calow, R.C. and Klinck, B.A. 2003. Groundwater and its Susceptibility to Degradation: A Global Assessment of the Problem and Options for Management. United Nations Environment Programme. Nairobi, Kenya.

North, D.C. 1990. Institutions, Institutional Change and Economic Performance. Cambridge University Press. Cambridge, NY.

Nowak, M., 2006. "Five Rules for the Evolution of Cooperation.” Science, vol. 314, pp. 15601563.

Oldekop, J., Bebbington, A., Truelove, N., Holmes, G., Villamarín, S. \& Preziosi, R. 2012.

"Environmental Impacts and Scarcity Perception Influence Local Institutions in Indigenous Amazonian Kichwa Communities.” Human Ecology, vol. 40, no. 1, pp 101-115.

Ostrom, E. 2005. Understanding Institutional Diversity. Princeton University Press. Princeton, NJ.

Ostrom, E. 1990. Governing the Commons: The Evolution of Institutions for Collective Action. Cambridge University Press. Cambridge; NY.

Pfeiffer, L. \& Lin, C. 2010. “Does Efficient Irrigation Technology Lead to Reduced Groundwater Extraction? Empirical Evidence.” Selected Paper prepared for presentation at the Agricultural and Applied Economics Association 2010 AAEA, CAES, and WAEA Joint Annual 
Meeting, Denver, Colorado, July 25-27, 2010.

Poteete, A.R., Janssen, M.A., \& Ostrom, E. 2010. Working Together: Collective Action, the Commons, and Multiple Methods in Practice. Princeton University Press, Princeton, NJ.

Quillen, E. 2000. "The Baca Ranch-a legacy from Mexico." Colorado Central Magazine, February 1. Accessed Aug. 11, 2014. http://cozine.com/2000-february/the-baca-ranch-a-legacyfrom-mexico/

Raymond, C. \& Robinson, G. 2012. “Factors affecting rural landholders' adaptation to climate change: Insights from formal institutions and communities of practice." Global Environmental Change, vol. 23, no. 1, pp. 103-114.

Reidsma, P., Ewert, F., Lansink, A. \& Leemans, R. 2010. “Adaptation to climate change and climate variability in European agriculture: The importance of farm level responses." European Journal of Agronomy, vol. 32, no. 1, pp. 91-102.

Rio Grande Water Conservation District (RGWCD). 2014. "Change In Unconfined Aquifer Storage West Central SLV.” Accessed Aug. 11, 2014. http://www.rgwcd.org/page1.html

Rosenzweig, C., Strzepek, K.M., Major, D.C., Iglesias, A., Yates, D.N., McCluskey, A. \& Hillel, D. 2004. "Water resources for agriculture in a changing climate: international case studies." Global Environmental Change, vol. 14, no. 1, pp. 345-360.

Skiles, S.M., Painter, T.H., Deems, J.S., Bryant, A.C. \& Landry, C.C. 2012. "Dust radiative forcing in snow of the Upper Colorado River Basin: 2. Interannual variability in radiative forcing and snowmelt rates." Water Resources Research, vol. 48, no. 1, pp. 1-11.

United States Geological Survey (USGS). 2014. “USGS 0822000: Rio Grande Near Del Norte, 
CO.” Accessed Aug. 11, 2014.

http://waterdata.usgs.gov/usa/nwis/nwisman/?site_no=08220000\&agency_cd=USGS

United States Geological Survey (USGS). 2013. Groundwater Depletion in the United States (1900-2008). Government Printing Office. Washington, DC.

United States Geological Survey (USGS). 1958. Groundwater Resources of the San Luis Valley Colorado: An Inflow-Outflow Study of the Area. US Government Printing Office. Washington, DC. Accessed Aug. 11, 2014. http://pubs.er.usgs.gov/publication/wsp1379

United States Department of Agriculture (USDA). 2012. "Historical Census Publications." Accessed Aug. 11, 2014.

http://www.agcensus.usda.gov/Publications/Historical_Publications/index.php

Varela-Ortega, C., Blanco-Gutierrez, I., Swartz C.H. \& Downing, T.E. 2011. "Balancing groundwater conservation and rural livelihoods under water and climate uncertainties: An integrated hydro-economic modeling framework." Global Environmental Change, vol. 21, no. 1, pp. 604-619.

Waha, K., Müller, C., Bondeau A., Dietrich J.P., Kurukulasuriya, P., Heinke, J. \& LotzeCampen, H. 2012. "Adaptation to climate change through the choice of cropping system and sowing date in sub-Saharan Africa." Global Environmental Change, vol. 23, no. 1, pp. 130-143.

Walker, B., Holling, C., Carpenter, S., \& Kinzig, A. 2004. "Resilience, Adaptability and Transformability in Social- Ecological Systems.” Ecology and Society, vol. 9, no. 2, 5.

Ward, F. \& Pulido-Velazquez, M. 2008. "Water conservation in irrigation can increase water use." Proceedings of the National Academy of Sciences of the United States of America, vol. 105, 
no. 47 , pp. $18215-18220$.

Wheeler, S., Zuo, A. \& Bjornlund, H. 2013. “Farmers' climate change beliefs and adaptation strategies for a water scarce future in Australia." Global Environmental Change, vol. 23, no. 1, pp. 537-547. 